contacts, Hope in some ways occupies a place of equal importance with Black, becaúse increasing numbers of industrialists (for example, the Tennant and Macintosh group) were in a position to benefit by contact with chemistry in the universities of Scotland. The popularity of chemistry with all classes in Scotland became so great that Hope sometimes had five hundred students attending his lectures, and outside the University, interest was every bit as great. He continued to lecture until 1844, when he was succeeded by Dr. William Gregory as independent professor of chemistry, fully a quarter of a century later than the foundation of an independent chair in the more highly industrialized city of Glasgow.

\section{LONDON'S WATER SUPPLY : SAFEGUARDING ITS PURITY IN PEACE AND WAR*}

\author{
By Lieut.-Colonel E. F. W. MACKenZie, O.B.E. \\ Director of Water Examination, Metropolitan \\ Water Board

\section{History}

TO story of London's water supply would be complete without some brief account of the historical background from which have emerged the methods of purification which now form our vital defences against the transmission of the germs of water-borne disease.

Prior to the fourteenth century, the citizens of London obtained their water from the River Thames and its tributary streams, or from springs and wells, which were plentiful. At that time the supply of water was a duty of the City Corporation, and it remained so until 1582, when a Dutchman named Peter Morrys was granted a 500-year lease at the nominal charge of $10 s$. per annum, with the right to supply water drawn from the River Thames by pumps driven by water-wheels set in one of the arches of the old London Bridge. This undertaking remained in the hands of the Morrys family until 1701, when it was transformed into a company, which also acquired the city conduits. Thus was the duty of supplying water to London relinquished by the constitutional authority and handed over. to private enterprise.

The next incident of note was the construction of the New River, opened in 1613, to convey pure water from springs in Hertfordshire to the City. The success of the New River Company led to the granting of power by Parliament to other companies for the purpose of supplying water, and between the years 1669 and 1806 no fewer than seven such companies were promoted. At the time of their formation, those of the companies which drew water from the River Thames had their intakes in the tidal pool, which became increasingly polluted by the ordure of the City. This led to the succession of serious epidemics of cholera in London during the nineteenth century.

Meanwhile, however, two important measures had been taken : first, the introduction in 1826 of filtration through sand, and second, the passing of the Metropolis Water Act of 1852, which prohibited the abstraction of water from the River Thames below

* Substance of a discourse delivered at the Royal Institution on December 8.
Teddington Weir and imposed, as a legal obligation, the filtration of all river-derived water and the covering of service reservoirs. The Metropolis Water Act of 1871 further contributed to the cause of purity by the appointment of an impartial water examiner who transmitted the reports of the analyst, at that time Prof. Frankland, to the Local Government Board, and who had other duties mainly inspectorial in nature. The water supply, however, continued to be the subject of public agitation, which culminated in the passing of the Metropolis Water Act of 1902, by which the Metropolitan Water Board was created to take over from the companies the duty of supplying water to London.

The Act of 1902 also placed upon the Board certain duties in connexion with laboratory examination designed to ensure the safety of the supply. This was the genesis of the present Water Examination Department, which came into being in November, 1905, with the appointment of Dr. (afterwards Sir) Alexander Houston as the first director. There were, thus, two persons whose duty it was to safe. guard the purity of the supply : first, the water examiner, who was an officer of the Local Government Board; and second, the director of water examination, who was an officer of the Metropolitan Water Board. This state of affairs continued until the appointment of water examiner was abolished in 1921 , and the duty of safeguarding the purity of the supply thus devolved entirely upon the director of water examination. In 1904 the Metropolitan Water Board finally took over the private companies, and the duty of supplying water to London was taken out of the hands of private enterprise and restored once more to the control of the representatives of the people, by whom it had been voluntarily surrendered more than two centuries before.

\section{Methods of Purification}

Until 1909, filtration through slow sand filters was relied upon for the purification of the river-derived water. Sir Alexander Houston, however, was responsible for the introduction of a number of revolutionary changes, chief among which were the regular use of water which had been purified by passage through a storage reservoir (1909), chlorination (1916), the use of primary mechanical filters antecedent to slow sand filtration (1923), and the use of ammonia as a means of reducing the tastes produced by chlorine alone.

The Metropolitan Water Board now comprises twelve filtration works and some sixty well stations. It supplies an area 575 square miles in extent containing more than $7,000,000$ people. The water is supplied through a distribution system of pipes 8,000 miles in length. Approximately two-thirds of the water is derived from the River Thames, onesixth from the River Lee, and one-sixth from deep wells sunk in the chalk.

The wells are usually of great depth and the water delivered from them is of excellent physical quality. For many years it was supplied without any treatment, but the increasing urbanization of the country districts around London and the excessive pumping which now takes place has led to a progressive deterioration in the quality of the water lying in the great chalk basin beneath London, and this has necessitated the chlorination of all well-derived water, but no other treatment is required.

The river waters, on the other hand, are heavily polluted and require somewhat elaborate purification. 
Briefly, the methods employed at the outbreak of war in 1939 were storage followed by filtration and chlorination.

The high rate of filtration made possible by the use of primary filters had detracted from the efficiency of the slow sand filters and had made it necessary to reinforce the purification processes at some works by the use of chlorine both before and after filtration. This prefiltration treatment has conveniently been termed 'prechlorination'.

These methods enabled the production of water in keeping with the standards of bacterial purity widely accepted prior to 1939. In that year, however, a more stringent test of purity received authoritative approval, and immediate steps were necessary to bring the water to the desired level. This involved the use of prechlorination at all filtration works, together with certain adjustments designed to render it more efficient, and an increase in the terminal dose of chlorine to a point at which it is, at times, liable to give rise to some taste in the water when it reaches the consumer. With this exception the methods have proved successful, but it will be possible to surmount the difficulty of occasional chlorinous tastes without some sacrifice in purity only by the construction of large tanks in which the water may be retained, before delivering it to consumers, for a sufficient time to enable a small dose of chlorine to do the work for which, at present, a comparatively large dose is required. The construction of these contact tanks has not been possible during the War, but it has become the accepted policy of the Board that they shall be provided when circumstances permit.

Unfortunately, chlorinous tastes are not the only ones with which water engineers are afflicted. The river waters have tastes which vary from 'earthy' to 'mouldy' ; the reservoirs are subject to algal growths which, by the liberation of essential oils, impart a wide range of tastes which have been variously described, the most common being 'aromatic', 'fishy' or 'grassy'. Until recently their complete elimination has been difficult or impossible, but the adaptation of activated carbon to waterworks practice has opened up a new field for the removal of tastes. Up to the present, it has necessarily been used by improvised methods, but it is hoped that it will be possible, after the War, so to adapt the works as to render this valuable treatment fully effective. The complete elimination of tastes from London's water supply should then be possible.

The Board has provided in the most ample manner for the statutory requirements in regard to water examination set forth in the Act of 1902. The Laboratories in Clerkenwell which were opened in 1938 are an outstanding example of a building which, in the highest degree, combines utility with architectural and artistic merit. Every unit in the building has been designed for a special purpose, and serves that purpose with the utmost efficiency. A high proportion of the staff have devoted most of their lives to particular aspects of water analysis.

The routine control of quality is exercised by the daily examination of samples representing the water in every stage of purification. Widespread random sampling from mains and consumers' taps throughout the area of supply is also practised, and enables the quality of the water as received by the consumer to be kept under frequent observation.

During the year 1943 no fewer than 38,351 such routine analyses were made. The work of the department is, however, by no means limited to this routine. Constant researches are made for improved methods, and special investigations are performed for the elucidation of purification and other problems which arise in connexion with the works. These have, in the past, contributed much to the sciences of water analysis and purification.

\section{War and the Water Supply}

Before describing the measures which were taken to protect the water supply of London against pollution from war damage, it would be well to picture what might have been the consequences had the water from one of the Board's major works become infected with the germs of typhoid, which is now, in England, the most to be feared of all the water-borne diseases.

Judged by past epidemics, it might be expected that infection of a filtration works of average size would, at the lowest estimate, result in 16,000 cases of typhoid with 1,600 deaths and the establishment of between 300 and 800 permanent carriers of the disease, as a reservoir of infection for the creation of further outbreaks. The significance of this can best be appreciated by comparison with the Croydon epidemic of 1937, in which there occurred 323 cases and 43 deaths. Many will recall the widespread feeling of alarm and the sense of insecurity which prevailed among those residing within the area affected by this comparatively minor outbreak.

It is easy to picture what might have been the effect upon the morale of the people of so disastrous an occurrence, and of the knowledge that each such incident would increase the probability of further similar epidemics.

High in the order of priority for protective measures came the necessity of ensuring that there should be no interruption in laboratory examination and control of the supply, for without this there would have been no means of assessing the need for, or the success of, other measures. Among the first steps to be taken were the selection of suitable buildings in comparatively safe areas and their conversion into alternative laboratories.

The use of , prechlorination was extended to all filtration works. This increased the main lines of defence to four, namely, storage, prechlorination, filtration and terminal chlorination. This was undoubtedly the most important factor in preserving the purity of the water pumped from the works, for there was no occasion upon which less than two of these lines remained intact.

The residual chlorine in the water passed into supply was increased to the highest level consistent with the avoidance of serious cause for complaint. This provided against pollution through infiltration of ground-water into broken filtered-water channels and also gave some protection against failure to effect complete sterilization of fractured mains as a result of either physical difficulties, which often existed, or the fallibility of human nature. The value of residual chlorine has frequently been exaggerated; but its limitations were fully appreciated and its presence was not permitted to allow of any relaxation in the more positive methods of protection.

The possibility of the introduction of chemical poisons into the water either deliberately, or accidentally, as by the use of poison-gas bombs, was countered by a system of guards at works and reservoirs, and by arrangements for the immediate testing at the works for poisons should there be any suspicion that the water might have become contaminated. 
It will be evident that chlorination was to play $\mathbf{a}_{\mathrm{a}}$ most important part in our defensive measures, and it was necessary that every possible step should be taken to prevent any interruption in this vital process. Although chlorination had been in use by the Board for a considerable time, it was still regarded as somewhat subsidiary to the older purification processes. This view had now to be revised, for acts of war might at any moment have rendered it the most important or, indeed, the only barrier against the spread of water-borne diseases. A wholesale programme of reconstruction was planned and received the immediate approval of the Board. This work involved the detailed consideration and replanning of more than 150 chlorination points.

There could be no doubt that the most serious danger would be created by the fracture of water mains and sewers in close proximity in the streets, resulting in the admission of sewage to the water mains. Protection against the consequences of such incidents was provided by the rapid closure of valves by turncocks and by instructions to the effect that no main should be put back into supply after repair until it had been thoroughly flushed and disinfected by chlorine. Whenever possible, repaired and sterilized mains were examined bacteriologically before being restored to supply, but frequently they were so urgently required for fire fighting that this could not be justified. Sterilization by chlorine was, however, never omitted. Special mobile chlorinators were provided, and the whole of London was divided into areas to each of which some were allotted. Central control was maintained and a reserve of chlorinators was held directly under my orders, thus enabling relief to be provided in districts where the work was exceptionally heavy. Some difficulties in the rapid sterilization of mains were encountered in the early days, due chiefly to the almost complete disorganization of communications, but these were rapidly overcome and, as experience was gained, the whole organization worked smoothly and without avoidable delay.

It was not only necessary to conserve the purity of the supply. "When the enemy resorted to fire raising, quantity became second only in importance to purity, for, without water, London might have been destroyed by fire. The greatest need for water frequently coincided with heavy damage to the works and consequent limitation of their output. Decisions had to be taken, often on the spur of the moment, as to the extent to which orthodox methods of purification might be discarded to increase production without imperilling the health of the people. There is no hard and fast line between a safe and an unsafe water, and such momentous decisions were not easily taken, for they had, of necessity, to be based upon personal opinion. It must be admitted that the taking of them was assisted by the gravity of the situation, and it can fortunately be said that there was no occasion when the quantity of pure water available was insufficient. nor was there, at any time, any deterioration in its bacterial purity. Local shortages there were, but these were due to the immense damage to the mains; and this was remedied with remarkable rapidity by the engineering staff of the Board.

\section{Emergency Water Supplies}

It was evident that, whatever precautions might be taken, interruption of piped supplies might occur. Arrangements were therefore made to deliver pure water by tank wagons and to provide emergency supplies if necessary from private wells and casual surface water sources. An organization was set up for the purification of these waters, which entailed the training in emergency purification methods of more than 7,000 volunteers.

During the aerial attacks on London, almost every conceivable form of damage which might have prejudiced the purity of the supply was inflicted upon the undertaking. Damage to sewers in the outskirts of London necessitated the discharge of untreated sewage into the rivers from which raw water supplies were drawn; reservoirs were cut off from the works by the destruction of aqueducts, thus necessitating the passing of unstored raw river water on to the filters ; bombs fell into the filter beds and caused shortcircuiting between the unfiltered and the filtered water channels. At times it was necessary to bypass the slow sand filters to enable the supply for firefighting to be maintained. Damage to the distribution system was particularly severe. In one night alone, more than five hundred mains were fractured and many became heavily charged with sewage.

All the necessary protective measures were, however, in readiness, and there is not a shred of evidence that the water supplied to London was at any time less safe than before the War. During the four years 1940-43, bacteriological analyses were performed on more than 50,000 samples drawn at the works, from mains pumping water into supply and throughout the distribution area, particularly in those localities where bomb damage had been heavy. Of these 50,000 samples, $99 \cdot 3$ per cent showed the absence of Bact. coli in $100 \mathrm{ml}$, that is to say, they conformed to the highest standard of bacterial purity despite the extensive damage which was frequently inflicted and the many opportunities for dangerous pollution which were created. This represents a purity, during these years of war, higher than ever before, and it has never been suggested by any health authority that a single case of disease occurred in London which might have been attributed to the water supply.

\section{POLYMER-PLASTICIZER INTERACTION}

By ELIZABETH M. FRITH and R. F. TUCKETT Department of Colloid Science, University of Cambridge

A $\mathrm{T}$ a meeting of the Plastics Group of the Socioty of Chemical Industry on November 17, 1944, polymer-plasticizer interaction was discussed. Owing to the wide range of the discussion and in view of topical interest in this subject, it has been thought desirable to present here a preliminary account which covers some of the points raised; more detailed papers will appear elsewhere. Some such general account seems to be overdue, as previous ideas on the subject would seem to need revision as a result of recent advances in polymer thermodynamics.

Though all thermoplastic polymers soften on heating, they also, in common with other organic compounds, tend to decompose as well. Moulding temperatures for any particular polymer must therefore be chosen to suppress this decomposition as much as possible. Some polymers can be moulded with negligible decomposition, whereas with others the temperatures required for moulding are too high, 